\section{Perspektivismens kompleksitet}

\section{Bert van Heel}

Tania $\emptyset$ rum (red.): Tcet på teksten, Kфbenhavn 1994 (Museum Tusculanums Forlag), $174 \mathrm{~s}$.

»Målet må være på grundlag af filologisk skoling at skabe en forening af tekstanalyse og behersket historisme, af synkroni og diakroni. Slagordet for denne bestræbelse kunne jo være: "perspektivismen««. Sådan ender Johan Fjord Jensens udmærkede introduktion Den ny kritik fra 1962 (ny udg. 1989). Efter en umiddelbar lasning af Tat $p a ̊$ teksten, skulle man tro, at hermed er ønsket opfyldt. Flere af denne antologis forfattere anvender en blanding af nærmest filologiske tilgange og tekstanalytiske greb videreudviklede af nykritikken. Og hvis man under »behersket historisme« forstår, at man sætter de tekstanalytiske resultater i relation til f.eks. tolknings-, kritik-, kultur- og/eller samtidshistoriske rammer, forekommer disse relationer også i antologien. Men tror man, at nykritikkens forestilling om helhedsteorien, hvor »alt i digtningen virker sammen i én totalstemning eller én totalmening «, ${ }^{1}$ kan man er intakt, kan man godt tro om igen. Denne lukning af teksten, sætter de fleste af antologiens forfattere sig imod. Dette er nok ikke så mærkeligt i en 90'er antologi, når man tager $\mathrm{i}$ betragtning, at vi i løbet af de sidste ca. 30 år er blevet introduceret til flere post-strukturalistiske teorier herhjemme, deriblandt den amerikanske, litterære dekonstruktion. De skiftende litteraturteoretiske skoler, deres teknik- ker og konsekvenser, kommer Tania $\varnothing$ rum da også meget kort ind på i sin indledning.

At bl.a. dekonstruktionen har været indflydelsesrig, fremgår af antologien, når man sætter Fjord Jensens målsætning i forhold til perspektivisme-begrebet, som det opfattes i Uffe Hansens (s.43) og i Frederik Stjernfelts (s.137) artikler. Her bliver en anderledes afg $\varnothing$ rende reference Nietzsches 1880 'er filosofi. Fjord Jensens perspektivisme-begreb henviser imidlertid til litteraturforskeren René Welleks syn på kunstværket som »både »evigt« - altså til en vis grad noget uforanderligt - og »historisk «, altså led i en historisk proces og selv underkastet udvikling «. ${ }^{2} \mathrm{Og}$ selv om Wellek og Nietzsche anvender begrebet bl.a. i et opgør med hhv. den »positivistiske historisme« og det positivistiske videnskabssyn, som havde vundet fodfæste i deres respektive fag, havde sidstnævnte et andet ærinde. At f.eks. naturlovmæssigheder skulle eksistere uafhængigt af en fysikers unders $\emptyset$ gelser er, ifølge Nietzsche, én (tilværelses-)interpretation blandt mange mulige. Denne fortolkning giver en mening og valoriseres (f.eks. at den er 'sand'). Men Nietzsche vil ikke vide af en kantiansk Ding an sich; tolkningens gyldighed lader sig ikke afgøre 'udefra'. Disse forudsatte normer, disse grundværdier, vurderes, ifølge Nietzsche, ikke af mennesket, hverken af dets 'bevidsthed' eller dets 'fornuft', derimod er det livet selv, der tvinger mennesket til at fastsætte værdier: »Det, der er værdiernes (og dermed tolkningernes) eksistentielle grundlag er »liv $\ll \mathrm{i}$ betydningen vilje til magt $\ll^{3}$. Heraf følger, at jo flere fortolkningsmuligheder der findes af sagen eller verden, altså jo flere perspektiver der 
gives på disse, jo mindre indsnævret bliver verden; disse er samtidig en forøgelse af viljen til magt. Nietzsches bevidstheds- eller fornuftskritik er rettet mod tanken om et universalperspektiv, hvorfra mennesket - som en gud - kan overskue det hele. Hermed sammenhængende tager Nietzsche også kritisk afstand fra en gammel substansmetafysik, hvor 'evige ideer' eller 'væren' bestemmes som konstante bag fænomenernes kontingente verden. Det, der ifølge Nietzsche forklarer fænomenernes foranderlighed, og som han opfatter som et realitetsprincip, er netop bevægeligheden $i$ selve fænomenerne.

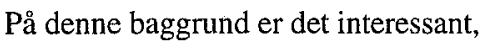
at flere af antologiens forfattere påberåber sig eller anvender flere fortolkningsmuligheder, flere perspektiver, i forhold til de læste tekster. De avler »utallige meninger« (Uffe Hansen), og »temaer, strukturer, meningsbærende sekvenser« (Tania Ørum) eller »figurer « (Frederik Tygstrup) dukker op, for herefter igen at forsvinde. Og selvom de metodisk-teoretiske indgangsvinkler er forskellige, finder man lignende resultater hos J $\emptyset \mathbf{r}$ gen Egebak, Nils Gunder Hansen (»tvetydigheden $\ll)$ og Frederik Stjernfelt.

Her skal imidlertid tilføjes, at det er nærlæsning som litteraturvidenskabelig grunddisciplin, der står i centrum - på tværs af litteraturteoretiske kontroverser. Derfor fors $\emptyset$ ger de fleste sig »mere frit og udogmatisk frem « (s.9); der lægges vægt på, at det er »forskellige versioner af nærlæsning i praksis« (s. 11). Det har bl.a. som konsekvens, at man kan karakterisere artiklerne som værende 'post-dekonstruktionistiske' i måden at tackle teksterne på. Her er ingen dogmatisk dekonstruktive læsninger. Besin- delsen oven på dekonstruktionen gennemsyrer denne antologi.

De behandlede forfatterskaber omfatter Henry James, Gertrude Stein, C.F. Meyer, Ernst Jünger, Franz Kafka, Orhan Veli Kanik, Robert Musil og D.H. Lawrence. For de flestes vedkommende ligger de analyserede tekster således indenfor et kort tidsspand: enkelte årtier før og efter århundredeskiftet. Som bekendt er det også en periode, hvor der sker radikale ændringer, med teknologisk fremskridt, kulturelle innovationer, men også Første Verdenskrig. Det skabte helt nye måder at tænke og erfare tid og rum på. ${ }^{4}$ Der kan således ligge en sammenhæng $i$, at netop disse forfatterskabers tekster analyseres i netop denne periode.

Artiklerne er fortrinlige. Nils Gunder Hansens bidrag (herefter NGH) adskiller sig fra de fleste $i$ antologien ved at lægge ud med en efterrefleksion over nærlæsningens styrker og problemer, som han mødte undervejs i forbindelse med et undervisningsforl $\varnothing b$ om Henry James' The Turn of the Screw fra 1898 (da.: Skruen strammes (1954/1968)). NGH havde her på forhånd besluttet at ville se James' tekst som en $\gg$ spøgelseshistorie (...) et stykke fantastisk litteratur i Todorovsk forstand « og ikke som en »psykopatologisk galskabshistorie eller en tekstuel immanent tvetydighed « (s.13). ${ }^{5}$ Herved hentydes der til tekstens tolkningshistorie, hvor den amerikanske litteraturkritiker Edmund Wilsons psykoanalytiske læsning fra 1934 væltede det kanoniserende syn på den som ghost story; i virkeligheden var den - ifølge Wilson - en syge- eller galskabshistorie med guvernanten som omdrejningspunkt. I 1977 foretog den amerikanske Shoshana Felman en dekonstruktionsin- 
spireret læsning, der - ifølge NGH - har den pointe, at spøgelseshistorie- og galskabshistorietolkningen kan »sættes som lige gode, fordi de har været lige gennemfфrlige i tolkningstraditionen« (s.15). NGH derimod hævder, at tolkningerne ikke kan gennemføres på samme niveau, idet nærlæsningen på forhånd har valgt side

Så vidt jeg kan se, tages der bl.a. udgangspunkt $i$ en slags læsningens fanomenologi. Nærlæsningen modstilles den første, præ-videnskabelige og ureflekterede 'Iystlæsning' (af NGH også kaldt 'fjernlæsning'), hvor læseren accepterer tekstens illusionshelhed, er solidarisk med udsigelsesinstanserne etc. For den videnskabelige nærlæsning derimod er ingen tekst længere uskyldig.

NGH kommer ind på 'karakterologien' som værende litteraturteoriens stedbarn under den nyere tids litteraturvidenskabelige beskæftigelse med retoriske og narrative forhold. Opfattelsen af tekstens karakterer sker derfor ofte intuitivt, baseret på »vitalistiske« kriterier, der forbliver uteoretiserede. Med udgangspunkt heri foreslår han, at » »tolkning ikke består $\mathrm{i}$ at gå længere ind i teksten«, men at gå ud af teksten og se hvad den siger om forhold i den menneskelige livsverden (Kundera)«. Det, der interesserer NGH er ikke »tekstens tvetydighed eller repræsentationens umulighed $\ll$, men $\gg$ hvilke problemstillinger teksten kan fortætte og dramatisere i sit komplekse udtryk «; at tvetydigheden herved overføres på eksistensen og livsverdenen er så en anden problematik (s. 26-27).

Tania Ørum (Tø) og Uffe Hansen (UH) anvender nærlæsninger af digte af hhv. Gertrude Stein og Conrad Ferdinand Meyer som afsæt for at inddrage en bredere kultur- og tolkningshistorisk kontekst. UH's nærlæsning er til dels et opgør med analyser, der fors $\emptyset$ gte at lase en entydig mening ud af teksten (f.eks. »ideologikritiske alvorsmænd (...) i Lukács kølvand « (s.33)). Det er blot at se på én pol i tekstens komplekse udsagn, mens nærlæsningen gør opmærksom på et komplementært »strukturkompleks af en ganske anden art« (s.34). På blandet filologisk/fænomenologisk/nykritisk vis åbnes der i den konkrete digtanalyse op for en ordentlig pose 'practical criticism'. UH fremlæser en »tiltagende $d e$ personalisering« (s.36). Digtets udsagnssubjekts identitet bliver uvis og det fører i løbet af digtet til »subjektets forsvinden« (s.37). Yderligere sker der en »derealiserende forvandling « (s.37) af sproget; det opløses og indgår i nye forbindelser. Endelig fremlæses der, hvordan tidsrelationerne i digtet bliver flertydige.

Lignende resultater făr $T \varnothing \mathrm{i}$ sine nærlæsninger af en digtrække af Gertrude Stein, hvor »appelsinen « står i centrum. Ordene frisættes i digtene fra grammatikkens og syntaksens spændetrøje, og det kaster laseren tilbage til det rent formale plan. På dette plan fremviser det forste digt en stram struktur: gentagelsesmønstre, tempusforskydninger, symmetrisk opbyggede linier, som yderligere forbindes $\gg$ af interne rim, ekkoer og lydforskydninger« (s.48). Herefter begynder spørgsmålene at melde sig, uden at der kan gives entydige svar; man må gå rent associativt til værks. Læseren kommer således på et hårdt arbejde. Biografiske indgangsvinkler interesserer ikke Tø. Mere interessante er tolkningsfors $\emptyset \mathrm{g}$, der v.h.a. nærlæsning fors $\emptyset$ ger at systematisere iagttagelser til en meningsfuld helhed. Som UH mener Tø 
dog også, at én bestemt læsestrategi på Steins tekster som helhed ikke kan lade sig gøre. Man befinder sig under læsningen $\mathrm{i}$ en slags flimmer, hvor stemaer, strukturer og meningsbærende sekvenser « dukker op, for herefter igen at forsvinde (s.56).

Ligesom UH indrager Frederik Stjernfelt (FS) Nietzsche i sin artikel om den nu 100-årige Ernst Jünger. Artiklen falder for så vidt udenfor begrebet om nærlæsning. Nok tager FS analytisk afsæt i Jüngers Das abenteuerliche Herz. $(1929 ; 1938)$ (da. udv. Kapriciøse indfald (1955)), men kun for derefter at give en historisk oversigt over hele Jüngers åndelige udvikling. I Das abenteuerliche Herz ( $\mathrm{AH})$ belyses Jüngers særegne æstetik og livsfilosofi baseret på den uudslettelige førstehåndsoplevelse, som Første Verdenskrig havde givet ham. Synsvinklen er den indre oplevelse, der vidner om rædslens $»$ forbundethed med processer hinsides erkendelsen« (s.140). FS sætter denne iskrækkens æstetik « i forbindelse med Nietzsches vitalisme i f.eks. Der Wille zur Macht. Bevidstheden opfattes af Jünger som en »overfladisk effekt af en dybere vilje-til-magt«. Dette anser FS for Jüngers »værst tænkelige arv fra Nietzsche« (s.150). En mere tiltalende nietzscheansk arv er ifølge FS Jüngers brud med den erkendelsesskepticisme, som nutidens derrideanske dekonstruktion står for. FS argumenterer for, at selv orn der er ligheder med dekonstruktionen, er erkendelsen - skønt perspektivisk - mulig ifølge Jüngers livsfilosofi, »fordi vi selv er levende og derfor forstår livets mekanismer fra os selv« (s.147). Verden kan således blive intelligibel.
Under inspiration af Edward Saids Orientalism (1978) gør Henning Goldbæk (HG) noget så interkulturelt forfriskende som at introducere den tyrkiske forfatter Orhan Veli Kanik (1914-54) (og til dels også Nâzim Hikmet (190263)), dennes forhold til den europæiske modernisme, samt forbindelsen til den førosmanniske periodes (13.-19. årh.) lyrik med dens mystiske rødder. HG beretter, at den tyrkiske litteratur siden det 19. årh.'s begyndelse, har haft en tilknytning til de europæiske litterære hovedstrømninger. Oversættelsesboomet af europæisk litteratur, fra Dante til Baudelaire, i løbet af det 19. årh. gør dog samtidig, at den tyrkiske litteratur til langt op i det 20. årh. lider af en trang til at efterligne. De moderne vestlige normer bliver for de moderne tyrkiske forfattere først autentiske på det tidspunkt, hvor der opstår en forbindelse $\mathrm{ml}$. den førosmanniske periode med dens folkelige tyrkiske poesi og religiøs lyrik. Den europæiske kultur bliver nu anvendt, ikke for at blive plagieret, men for at levendegøre en »tyrkisk historie, der er anderledes end hovedstrømningen under Sultanatet« (s.69). HG beretter bl.a. om, hvordan der efterhånden sker et opgør med hoflyrikken. Alt det ornamentale, symbolet og metaforen må afskaffes til fordel for en direkte benævnelse af verden. Artiklen afslutter med beskrivelse af, hvorledes den nyeste generation af islamiske lyrikere søger at forene en puristisk sprogrenselse med traditionens religiøse sprogmagi.

Med udgangspunkt i sammenligningen af et romanfragment Der Heizer og et dagbogsnotat om en drøm, der foregår sammesteds (New Yorks havn), søger Jørgen Egebak (JE) en forklaring på, hvad der synes at være foregået under 
Franz Kafkas 'gennembrud' i 1912, og hvilken 'hemmelige forbindelse' - som Kafka selv antød - der består ml. tekster som Das Urteil, Die Verwandlung og Der Verschollene. I forhold til Kafkas tidligere litterære produktion, hvor han havde en tilbøjelighed til at identificere sig med sine hovedpersoner, sker der i drømmenotatet og romanfragmentet ikke bare en adskillelse af »det skrivende jeg (...) fra det skrevne jeg«, men yderligere en »adskillelse af det skrivende jeg og det empiriske jeg, forfatteren Kafka under skriveprocessen, og Kafka når han ikke skriver« (s.88). En sammenlignende læsning af de to tekstafsnit viser, ifølge JE, at adskillelsen af det skrivende fra det skrevne jeg synes at beskytte Kafka mod voldsomme kræfter af bl.a. seksuel karakter. Muligheden for at kunne håndtere sådanne situationer, nemlig det at skrive, synes dog samtidig at indebære en fortrængning af kropslig nærhed, således at man kan tale om »kroppens litterære transsubstantiation « (s.95). En vigtig forudsætning for denne adskillelse af krop og skrift, der samtidig holder den litterære produktivitet $i$ gang synes at være Kafkas forhold til Felice Bauer i efteråret 1912. Deres brevveksling er præget af distance, ingen kropslig nærhed.

Frederik Tygstrups (FT) tema er forholdet mellem fiktion og refleksion som et led i det 20. årh.'s udvikling af romanen. Hvor den klassiske romanhelts handlinger tidligere stod i forgrunden, er disse hos den moderne romanhelt afløst af »en grublen«, idet denne »ikke langere ved, hvordan han skal handle« (s.107) Herved træder refleksionen i forgrunden. FT inddrager Adornos formhistoriske overvejelser, som viser fiktion og refleksion som »to varia- ble fremstillingsstrategier «. Refleksionen selvstændiggøres og bliver selv til stof for fiktiv bearbejdning

Bl.a. gennem sammenligninger med andre af samtidens forfattere (Hermann Broch, Thomas Mann), søger FT at vise, hvordan ovennævinte vekselvirkning bevidst markeres i Robert Musils ufuldførte Der Mann ohne Eigenschaften (1930-1943) (da.: Manden uden egenskaber (1994)). Nærlæsningerne viser bl.a., at der i refleksionspassagerne ikke »tænkes over « situationerne, men at der »tænkes $u d$ fra « disse; herved sker der nok en »intens betydningsproduktion «, men den fører ikke til en »afsluttet meningsproduktion « (s.116). Det nydannende hos Musil bliver opfattelsen af tanken som en proces, der bearbejdes på samme măde, som »handlende og lidende romanpersoner $\ll$; denne fremstilling af »tankende tanker « bliver selv til en "virkelig handling (s.117). Fiktionen hos Musil repræsenterer ikke længere et forudsat, stabilt realitetsniveau, men bliver en fortløbende konstruktion af virkelighedsplaner. Musil's roman kan opfattes som en æstetisk, refleksiv erkendelsespraksis, hvor figurer og tanker dukker op, for kort derefter at forsvinde igen.

Karin Højersholts (KH) artikel om D.H. Lawrence falder for så vidt ud af rækken, idet der ikke tages udgangspunkt i et litterært værk, men i en rejseberetning til etruskiske udgravninger, som blev udgivet to år efter denne forfatters død i 1932 under navnet Etruscan Places. Læsninger af tekstuddrag sættes i relation til en bredere biografisk kontekst, hvorfra der trækkes linier til bl.a. dele af Lawrences forfatterskab. Artiklens læsninger fremhæver Lawrences yderst sensitive sprogkunst. Denne 
sættes igen i relation til hans menneskesyn og personlige livsanskuelse, der går ud på at se drømmen »om det uspolerede menneske virkeliggjort« (s.163). Denne mennesketype ser Lawrence virkeliggjort i fortolkningen af etruskergravernes udsmykninger, der modstilles romerne, som på ufordelagtig vis synes at have knægtet disse principper. Fra Lawrences civilisationskritiske indstilling trækkes der linier til samtidens USA og det Britiske Imperium, der ses som udtryk for en »livsfornægtende modernitet《 (s.163). Lawrence var i sin »»leadership«-periode« i 20-erne tiltrukket af en forestilling, som kan karakteriseres som »fascistoid «. En efterfølgende tematiske kursændring - dog med naturbegejstringen intakt - fremhævede nu »kærlighedens primat« som vitalistisk livsudfoldelse, klarest udtrykt i Lady Chatterley's Lover $\gg$ med sit økologiske sexualevangelium « (s.163-64). KH forsætter analyserne med at pendle mellem rejseberetningen, forfatterskabet og beslægtede synspunkter hos andre tænkere.

Således demonstreres. gennem artiklerne »nærlæsningens anvendelsesmuligheder«. Også hvor »dens grænser går« (s.10), jfr. NGHs artikel. Og selv om det ikke har været meningen med denne antologi, kunne netop 'grænsesøgningen' ud fra et tekstteoretisk synspunkt kritiseres. Tekst/kontekst problematikken bliver ikke i nævneværdigt omfang diskuteret som teoretisk problem. Udover en traditionsbevidsthed hvad nærlæsningsteknikker og metoder angår, siger Tat på teksten noget om litteraternes forskellige ståsteder her midt i 90'erne: på eklekticistisk vis, kan man beskæftige sig med det man vil, og frit anvende litteraturteorier. Alt efter inte- resse. Bare der vises en sammenhæng $i$ argumentationsrækken. For så vidt 'afspejler' denne antologi meget godt situationen i 90'ernes danske litteraturvidenskab.

\section{Noter}

1. Cf. Johan Fjord Jensen: Den ny kritik, Kbh. (1962), s. 106

2. Cf. Fjord Jensen (1962), p.89, 90.

3. Cf.Jørgen Hass: Illusionens filosofi. Studier $i$ Nietzsches firser-manuskripter, Odense (1982), p.49. Hvis ikke andet er angivet, er det følgende baseret på Hass' fortolkning af Nietzsches manuskripter. 4. Jvf. Stephen Kern: The Culture of Time and Space 1880-1918, London 1983. Kerns analyse af teknologiens effekter på masserne såvel som intellektuelle og kunstnere i dennne periode, inddrager interessant nok flere af de i antologien behandlede forfatterskabers værker og synspunkter.

5.Som NGH selv i en note gør opmærksom på, har han i artiklen »Når skruerne strammes -om litterære tolkningsstrategier og -kontroverser, eksemplificeret udfra Henry James' 'The Turn of the Screw' «, in $K \& K 70$ (1991), p. 25-56, på udførlig og kritisk vis fors $\emptyset \mathrm{gt}$ at vise de problematikker, som Shoshana Felmans ' 'læsnings-på-læsning'-strategi i forhold til James' tekst bringer med sig. I samme nummer har $\mathrm{NGH}$, i uddrag og kraftigt redigeret, oversat Felmans artikel: »At stramme fortolkningens skrue «, p.8-24. Jeg vil anbefale læsere, som er interesserede i de af NGHs anførte problematikker at læse de nævnte artikler $i$ sammenhæng med denne anmeldelse. 